\title{
Rural vs Urban: Teachers' Obstacles and Strategies in Mathematics Learning During COVID-19 Pandemic
}

\author{
${ }^{1}$ Fadhil Zil Ikram \& ${ }^{2}$ Rosidah \\ ${ }^{1}$ Universitas Negeri Malang, Malang, Indonesia \\ ${ }^{2}$ Universitas Negeri Makassar, Makassar, Indonesia \\ 1dhilikram@gmail.com \\ ${ }^{2}$ rosidah.unesa@gmail.com
}

\begin{abstract}
During the pandemic of COVID-19, numerous obstacles arose in education, and some strategies were necessary to tackle them. This study adopted a qualitative approach to investigate teachers' difficulties in mathematics learning in rural and urban areas and how they solved them. The findings revealed that motivation, productivity, and activity are the main problems of the teachers. Accessibility also poses a difficulty for teachers in rural areas. Several strategies were implemented to solve these obstacles, including using technology, maintaining communication with families, providing flexibility, reducing the number of tasks and quizzes, and peer teaching.
\end{abstract}

Keywords: rural, urban, strategies, obstacles, mathematics learning.

\section{Introduction}

COVID-19 has been trending all around the world due to its impact on various fields, including education. Teachers and students must adapt to the new learning situation, especially virtual learning (Cheng, 2020). This type of instruction allows students who have limited access to get an education (Febrianto, Mas'udahdah, \& Megasari, 2020; Radha, Mahalakshmi, Kumar, \& Saravanakumar, 2020). Moreover, Febrianto et al. (2020) said that distance learning also enables teachers to create a learning space for discussion.

However, due to sudden adaption to the current situation, various virtual learning problems surely arise. A preliminary study conducted by observing social media revealed that many people complain about distance learning. The most common one was accessibility, with limited internet access students could not fully participate in the learning process. Therefore, devising plans for learning activities is crucial for teachers.

There is an exponential increase in the number of studies regarding mathematics education during the pandemic in Indonesia. For example, there is a study examining the effectiveness of "Edutainment" as a learning media (Pratama, Lestari, \& Astutik, 2020) and the use of WhatsApp and Zoom, which facilitate mathematics learning in terms of students' mathematics achievement (Kusuma \& Hamidah, 2020; Yensy, 2020). Additionally, there is one investigating the mathematics learning process during the pandemic (Irfan, Kusumaningrum, Yulia, \& Widodo, 2020; Wiryanto, 2020), and a study that explored the difficulties of undergraduate students of mathematics education during their distance learning (Annur \& Hermansyah, 2020). A study by Mailizar et al. (2020) investigated mathematics teachers' views on distance learning implementation. The difference in learning obstacles most likely to occur due to the difference in residential areas during the pandemic, but a study comparing teachers' strategies in rural and urban areas is a rarity. Therefore, the researcher 
found it necessary to conduct a study investigating mathematics teachers' obstacles and strategies from rural and urban areas to implement mathematics learning during the pandemic.

\section{Methods}

This study adopted a qualitative approach to investigate mathematics teachers' obstacles and strategies during COVID-19 pandemic. Ten mathematics teachers, consisting of four teachers from urban areas and six teachers from rural areas, participated in an in-depth interview regarding their mathematics teaching problems and how they tackled them.

Telephone or chatting application was employed to collect data. The interview conducted followed a protocol that contains two main questions: the obstacles that the teachers encountered in teaching mathematics during the pandemic, and the strategies they employed tackle the issues.

The interview results were then analysed to compare obstacles and strategies in mathematics learning during pandemic from the perspective of teachers in rural and urban areas. The analysis methods used were data condensation, data display, verification, or concluding (Miles, Huberman, \& Saldana, 2014). In data condensation, the researcher thoroughly scanned the interview transcripts to look for relevant information regarding teachers' struggles and strategies and highlighted them. The other information was left to be considered later to look for related and unique information or findings. The data were displayed in a table to look for patterns and consistencies (data display). Then the researcher drew a conclusion based on the data (verification or concluding).

\section{Results and Discussion}

After conducting the interview, asking the teachers about the obstacles they encountered in distance mathematics' learning during a pandemic situation and the strategies to solve them, the results were analysed as follows.

Table 1

Result of the Study

\begin{tabular}{|c|c|c|}
\hline Obstacles & Teachers & Strategies \\
\hline $\begin{array}{l}\text { Less motivated } \\
\text { Less productive } \\
\text { Less active }\end{array}$ & Urban & $\begin{array}{l}\text { Use of various media such as WhatsApp, Zoom Quizizz, } \\
\text { YouTube, and Google Classroom. } \\
\text { Utilising many educational platforms. } \\
\text { Asking students to create a product related to the topic taught. } \\
\text { Maintaining communication with students' families. } \\
\text { Reducing the number of assignment and quizzes. }\end{array}$ \\
\hline $\begin{array}{l}\text { Students' access to } \\
\text { learning }\end{array}$ & Rural & $\begin{array}{l}\text { Homeroom teachers visiting and giving the students teaching } \\
\text { materials to students without access to the internet. } \\
\text { Giving flexibility for students with accessibility problems. } \\
\text { Asking students to help each other by borrowing or lending their } \\
\text { phone or laptop or borrowing the gadgets from their relatives or } \\
\text { neighbours. } \\
\text { Peer-teaching }\end{array}$ \\
\hline
\end{tabular}


Table 1 provides information about mathematics teachers' obstacles in rural and urban schools during the pandemic. Commitment to learning becomes one of the issues during the pandemic (Engelbrecht, Llinares, \& Borba, 2020), and in this study, they are in the forms of motivation, activity, and productivity. Interviews with the teachers revealed the source of these difficulties.

Table 2

Interview Excerpt

\begin{tabular}{|c|c|c|}
\hline Teachers & Interviewer & Answer \\
\hline $\mathrm{T} 1$ & $\begin{array}{l}\text { Why did the students become less } \\
\text { motivated, less productive, and less } \\
\text { active? }\end{array}$ & $\begin{array}{l}\text { They prefer face-to-face learning. They want to } \\
\text { experience the classroom's physical } \\
\text { environment. }\end{array}$ \\
\hline $\mathrm{T} 2$ & $\begin{array}{l}\text { Why did the problem with students' } \\
\text { commitment to learning happen? }\end{array}$ & $\begin{array}{l}\text { They did not like distance learning. They have } \\
\text { a better understanding when the teachers } \\
\text { deliver the material directly. For mathematics, } \\
\text { all of them even said that face-to-face learning } \\
\text { is a must. }\end{array}$ \\
\hline $\mathrm{T} 3$ & $\begin{array}{l}\text { Do you know why the students have a } \\
\text { commitment problem? }\end{array}$ & $\begin{array}{l}\text { Yes, they prefer meeting directly in the } \\
\text { classroom. }\end{array}$ \\
\hline
\end{tabular}

Table 2 shows that although many students were already capable of studying through internet resources, they still prefer face-to-face learning. Several studies also reported that many students still prefer offline learning (Febrianto et al., 2020; Radha et al., 2020).

One of the strategies used was decreasing the number of assignments. According to the mathematics teachers interviewed, the number of assignments contributes to students' anxiety and stress, leading to a decrease in their commitment to learning. Nonetheless, because of virtual learning, Nguyen et al. (2020) said that teachers should increase the number of tasks. They suggested that this strategy prevents students from cheating. However, in this study, the teachers prioritise their students' mental health to maintain their immunity to the virus. It follows Kamsurya (2020) findings, stating that people should support and increase the immune system to avoid the coronavirus.

Another strategy employed was the optimisation of the use of learning media. The teachers interviewed utilised social media and many learning platforms to implement their learning. George (2020) also proposed some of the strategies used: online teaching platforms, learning applications, and YouTube videos. In this study, some teachers even asked the students to create a video presenting a mathematical concept.

Although both teachers' strategies were similar, in-depth interview showed a slight distinction. Teachers from rural areas revealed that homeroom teachers visited their students with accessibility problems once every two or three weeks to maintain communication with family. The family greatly influences students' learning process during the pandemic (Febrianto et al., 2020). Many students neglected their assignments because they must help their parents' jobs. The teachers then discussed it with the parents about the ideal learning for their children.

Both teachers from rural and urban areas prefer using virtual conference applications to teach. Not only did it become the trends (Pratama, Azman, Kassymova, \& Duisenbayeva, 
2020), but some studies (Kusuma \& Hamidah, 2020; Yao, Rao, Jiang, \& Xiong, 2020) also suggested them. However, teachers from rural schools have to consider their students' internet quota by focusing more on the WhatsApp group or providing a recorded video that still has effectiveness (Morgan, 2020; Yensy, 2020). Applications such as Zoom were used only several times to minimise students' internet data usage.

The next obstacle was accessibility to the internet. Many students worldwide do not have access to distance learning or even just to read reading resources (Bakker \& Wagner, 2020; Engelbrecht et al., 2020; Morgan, 2020; Sá \& Serpa, 2020). In Indonesia, such a problem is also present (Bahasoan, Ayuandiani, Mukhram, \& Rahmat, 2020; Febrianto et al., 2020; Hebebci, Bertiz, \& Alan, 2020; Kamsurya, 2020; Mailizar et al., 2020). However, in this study, only the teachers from rural areas reported the problem. The teachers have to present equity and flexibility to the students. In rural schools, they gave homeroom teachers teaching materials to visit their students with accessibility problems. Such an effort was similar to the strategies employed by China's government, where they asked the social worker to ensure students participate in learning (Cheng, 2020). Moreover, the interview revealed that the mathematics teacher from rural schools even implemented peer-teaching or asked students to borrow gadgets (phone or laptop) from relatives, friends, and neighbours to ensure learning participation.

Interview results showed that the teachers have sufficient skill to utilise learning media in delivering mathematics instruction during the pandemic. Similar findings also reported that teachers become more innovative and creative in optimising their teaching (Febrianto et al., 2020; Lestari \& Gunawan, 2020). In this study, the teachers provide a solution for students without internet access and those with unlimited access.

\section{Conclusion}

The study results implied that teachers' obstacles in rural and urban areas are quite the same: students were less motivated, less productive, and less active. The only difference was the internet accessibility problems. Regarding teachers' strategies, they include the use of various media; peer teaching and cooperation among students (rural schools); doing projects; visiting (rural schools), consulting, and maintaining communication with students' families; reducing the number of quizzes and assignments; and giving flexibility to students with limited internet access.

\section{References}

Annur, M. F., \& Hermansyah, H. (2020). Analisis Kesulitan Mahasiswa Pendidikan Matematika dalam Pembelajaran Daring pada Masa Pandemi COVID-19. Paedagoria: Jurnal Kajian, Penelitian Dan Pengembangan Kependidikan, 11(2), 195-201.

Bahasoan, A., Ayuandiani, W., Mukhram, M., \& Rahmat, A. (2020). Effectiveness of Online Learning in Pandemic Covid-19. International Journal of Science, Technology \& Management, 1(2), 100-106. 
Bakker, A., \& Wagner, D. (2020). Pandemic: lessons for today and tomorrow? Educational Studies in Mathematics, 104, 1-4.

Cheng, X. (2020). Challenges of "School' s Out, But Class's On" to School Education: Practical Exploration of Chinese Schools during the COVID-19 Pandemic. Sci Insight Edu Front, 5(2), 501-516. https://doi.org/10.15354/sief.20.ar043

Engelbrecht, J., Llinares, S., \& Borba, M. C. (2020). Transformation of the mathematics classroom with the internet. ZDM Mathematics Education, 52, 825-841. https://doi.org/10.1007/s11858-020-01176-4

Febrianto, P. T., Mas'udahdah, S., \& Megasari, L. A. (2020). Implementation of Online Learning during the Covid-19 Pandemic on Madura Island, Indonesia. International Journal of Learning, Teaching and Educational Research, 19(8), 233-254. https://doi.org/10.26803/ijlter.19.8.13

George, M. L. (2020). Effective Teaching and Examination Strategies for Undergraduate Learning During COVID-19 School Restrictions. Journal of Educational Technology Systems, 49(1), 23-48. https://doi.org/10.1177/0047239520934017

Hebebci, M. T., Bertiz, Y., \& Alan, S. (2020). Investigation of Views of Students and Teachers on Distance Education Practices during the Coronavirus (COVID-19) Pandemic. International Journal of Technology in Education and Science, 4(4), 267282.

Irfan, M., Kusumaningrum, B., Yulia, Y., \& Widodo, S. A. (2020). CHALLENGES DURING THE PANDEMIC: USE OF E-LEARNING IN MATHEMATICS LEARNING IN HIGHER EDUCATION. Infinity Journal of Mathematics Education, 9(2), 147. https://doi.org/10.22460/infinity.v9i2.p147-158

Kamsurya, R. (2020). Learning Evaluation of Mathematics during the Pandemic Period COVID-19 in Jakarta. International Journal of Pedagogical Development and Lifelong Learning, 1(2), ep2008. https://doi.org/10.30935/ijpdll/8439

Kusuma, J. W., \& Hamidah, H. (2020). Perbandingan Hasil Belajar Matematika dengan Penggunaan Platform WhatsApp Group dan Webinar Zoom dalam Pembelajaran Jarak Jauh pada Masa Pandemik COVID 19. Jurnal Ilmiah Pendidikan Matematika, 5(1), 97106.

Lestari, P. A. S., \& Gunawan, G. (2020). The Impact of Covid-19 Pandemic on Learning Implementation of Primary and Secondary School Levels. Indonesian Journal of Elementary and Childhood Education, 1(2), 58-63.

Mailizar, M., Almanthari, A., Maulina, S., \& Bruce, S. (2020). Secondary School Mathematics Teachers' Views on E-learning Implementation Barriers during the COVID-19 Pandemic: The Case of Indonesia. Eurasia Journal of Mathematics, Science and Technology Education, 16(7).

Miles, M. B., Huberman, A. M., \& Saldana, J. (2014). Qualitative Data Analysis: A Methods Sourcebook (3rd ed.). SAGE Publications. 
Morgan, H. (2020). Best Practices for Implementing Remote Learning during a Pandemic Best Practices for Implementing Remote Learning during a Pandemic. The Clearing House: A Journal of Educational Strategies, Issues, and Ideas, 93(3), 134-140. https://doi.org/10.1080/00098655.2020.1751480

Nguyen, J. G., Keuseman, K. J., \& Humston, J. J. (2020). Minimise Online Cheating for Online Assessments During COVID-19 Pandemic. Journal of Chemical Education, 97(9), 3429-3435. https://doi.org/10.1021/acs.jchemed.0c00790

Pratama, H., Azman, M. N. A., Kassymova, G. K., \& Duisenbayeva, S. S. (2020). The Trend in Using Online Meeting Applications for Learning During the Period of Pandemic COVID-19: A Literature Review. Journal of Innovation in Educational and Cultural Research, 1(2), 58-68. https://doi.org/10.46843/jiecr.v1i2.15

Pratama, L. D., Lestari, W., \& Astutik, I. (2020). Efektifitas Penggunaan Media Edutainment di Tengah Pandemi COVID-19. AKSIOMA: Jurnal Program Studi Pendidikan Matematika, 9(2), 413-423.

Radha, R., Mahalakshmi, K., Kumar, V. S., \& Saravanakumar, A. R. (2020). E-Learning during Lockdown of Covid-19 Pandemic: A Global Perspective. International Journal of Control and Automation, 13(4), 1088-1099.

Sá, M. J., \& Serpa, S. (2020). The Global Crisis Brought about by SARS-CoV-2 and Its Impacts on Education: An Overview of the Portuguese Panorama. Sci Insight Edu Front, 5(2), 525-530. https://doi.org/10.15354/sief.20.ar039

Wiryanto, W. (2020). Proses Pembelajaran Matematika di Sekolah Dasar di Tengah Pandemi COVID-19. Jurnal Review Pendidikan Dasar: Jurnal Kajian Pendidikan Dan Hasil Penelitian, 6(2), 125-132.

Yao, J., Rao, J., Jiang, T., \& Xiong, C. (2020). What Role Should Teachers Play in Online Teaching during the COVID-19 Pandemic? Evidence from China. Sci Insight Edu Front, 5(2), 517-524. https://doi.org/10.15354/sief.20.ar035

Yensy, N. A. (2020). Efektifitas Pembelajaran Statistika Matematika melalui Media WhatsApp Group Ditinjau dari Hasil Belajar Mahasiswa (Masa Pandemik Covid 19). Jurnal Pendidikan Matematika Raflesia, 05(02), 65-74. 